\title{
Effect of Spraying by Some Substances on Low Temperature Stress for Growth and Productivity in Late Peas (Pisum sativum L.) Planting under the Middle Egypt Region Conditions Abdel-Aziz, M. A. and R. H. M. Geeth \\ Self- Pollination Veget. Dept.; Hort. Res. Inst.; Agric., Res. Center, Giza, Egypt. \\ Corresponding author: E-mail:drmedhataziz@yahoo.com
}

\section{ABSTRACT}

Two field experiments were carried out at Sids Horticulture Research Station, Beni Sueif Governorate, Agriculture Research Center, Egypt during the two successive winter seasons of 2015/2016 and 2016/2017. To study the effect of foliar spraying with two concentrations from three stimulate substances i.e. Salicylic acid at a rate of $0.5 \mathrm{and} 1 \mathrm{~g} / \mathrm{L}$, Selenium at a rate of 5 and $10 \mathrm{mg} / \mathrm{L}$, Green miracle at a rate of 3 and $6 \mathrm{~cm}^{3} / \mathrm{L}$ beside the control (spraying with tap water) and their interaction on growth characters, pollen grains viability \%, yield and its components as well as some chemical constituents in the leaves and the seeds under low temperature stress in the late peas plantations which prevailing under the middle Egypt region conditions during this period of the year for two peas (Pisum sativum L.) cultivars i.e. Entsar 1 and Master B. The experimental design was splitplot; two pea cultivars were devoted in the main plots and foliar applications of three stimulate substances at the two concentrations of each of them arranged in sub plots. Seeds were sown in the $1^{\text {st }}$ week in December during the two seasons. The results showed that the superiority of Entsar 1 cultivar in the studied characters of growth i.e. plant height, number of branches and dry weight/ plant in addition to the percentage of the vitality of the pollen grains, total pods yield (ton/ fed) and its components as well as the chemical content of leaves and seeds i.e. chlorophyll, total sugars, proline, nitrogen, phosphorus and potassium in leaves as well as total sugars and protein in seeds as compared with Master B cultivar. The results also showed that the foliar spraying with the Green miracle at a concentration of $3 \mathrm{~cm}^{3} / \mathrm{L}$ which was the best stimulant substance markedly improve most of the studied characters. The results of the interaction between the two factors had a significant effect on the studied characters of growth, pods yield and its components as well as the chemical content of leaves and seeds under these conditions. The best results were obtained from foliar spraying of Entsar $1 \mathrm{cv}$. by the Green miracle substance at a concentration of $3 \mathrm{~cm}^{3} / \mathrm{L}$ followed by foliar spraying with the highest concentrations of Selenium and Salicylic acid, respectively.

Keywords: Low temperature stress, Pea cultivars, Green miracle, Selenium, Salicylic acid and Feddan $=4200 \mathrm{~m}^{2}$

\section{INTRODUCTION}

Pea is a member of the Fabaceae family, considered one of the most important and popular vegetable crops cultivated in Egypt for local market and exportation. Peas are a nutritious legume, containing 15 to $35 \%$ protein and high concentrations of the essential amino acids i.e. lysine and tryptophan. Pea also contains high levels of carbohydrates and is low in fiber (Elzebroek and Wind, 2008). Regarding low temperature stress, Clarke et al. (2004) concluded that minimum germination of pea plants occurs in soil temperature from 4 to $6{ }^{\circ} \mathrm{C}$ while optimum germination occurs at 16 to 18 ${ }^{\circ} \mathrm{C}$. Chilling tolerance for pollen of chickpea as the survival of pollen exposed to temperatures $<15{ }^{\circ} \mathrm{C}$, but not $<7{ }^{\circ} \mathrm{C}$. In this orientation, Kumar et al. (2016) commented that low temperature is one of the major factors that limit crop production and reduce yield, low temperature may affect several aspects of crop growth i.e. survival, cell division, photosynthesis, water transport, growth and finally crop yield. Plants differ in their tolerance to chilling stress, was noticed which occurs at temperature less than $10{ }^{\circ} \mathrm{C}$ but above $0{ }^{\circ} \mathrm{C}$, chilling and freezing temperatures cause severe deformation of cell membranes, loss of membrane integrity, solute leakage, dehydration of intracellular spaces and physical damage by forming ice crystals and the inhibition of reproductive development and also, results in oxidative stress. Cool season crops are highly sensitive to low temperature stress during flowering stage and early pod-formation phase. Chilling causes more loss in areas where the growing season is short or crops sensitive to frost are chickpea, lentil, peas and long-duration pigeon pea.

Salicylic acid substance as a foliar application, which acts as an endogenous growth regulator of phenolic nature, stomatal closure, the activity of enzymes related to the carbon metabolism, such as Rubisco and acts as potential non-enzymatic antioxidant, antioxidant system has an important role in the response of plants to low temperatures as well as in decreasing cold damage. One of the most important parts of this system is represented by antioxidant enzymes, such as superoxide dismutase, peroxidase and catalase. Antioxidant enzymes allow the elimination of reactive oxygen species (ROS), such as superoxide anion $\left(\mathrm{O}_{2}^{-}\right)$and hydrogen peroxide $\left(\mathrm{H}_{2} \mathrm{O}_{2}\right)$. Excessive production of reactive oxygen species during cold stress can cause oxidative damage to membrane lipids, proteins and nucleic acids (Mutlu et al., 2013). Heba et al. (2015) concluded that spraying snap bean plants with Salicylic acid substance as a foliar application especially at the highest concentration i.e. at a rate of $1.0 \mathrm{Mm} / \mathrm{L}$ significantly increased most characters of vegetative growth, yield and its contents as well as some chemical components in snap bean plants compared to untreated plants.

As for, the beneficial effects of Selenium element, Egypt is a country with a low content of Selenium in its soil, which is quite low, causing a Selenium deficiency in the human diet (Tapiero et al., 2003). Cultivation of plants enriched with Selenium could be an effective way of producing Se-rich foodstuffs and thereby increase health benefits, Selenium plays a role in the prevention of atherosclerosis, specific cancers, heart disease, arthritis and altered immunological functions. In another side, Hawrylak-Nowak et al. (2010) demonstrated that Selenium enhanced resistance to certain abiotic stresses i.e. chilling. Low temperature stress can promote the accumulation of reactive oxygen species in the chloroplasts and decrease the antioxidant activity of wheat seedling under cold stress. A decrease in antioxidant enzyme activity is noticed during leaf senescence. Selenium can prevent oxidative damage and 
increase tolerance of plants exposed to low temperature, because of its structural role in the synthesis of glutathione peroxidase enzyme in Selenium-treated cucumber plants. Boghdady et al. (2017) declared that foliar spray with Selenium at the concentration up to 10 ppm selenium/ L significantly increased growth, yield and chemical composition of faba bean plants.

Regarding, the favorable effects of Green miracle as an antitranspirant which contains total amino acids not less than $3 \%$, In this orientation, Geeth and Galal (2014) indicate that Palmoral pea cv. significantly enhanced the vigor growth than Jaguar pea cv. There was a significant increase with spraying amino acids (12\% free amino acids) at a rate of $100 \mathrm{ppm} / \mathrm{L}$ as well as in the interaction between the varieties and spraying amino acids in some characters of vegetative growth, yield and its contents as well as some chemical components as compared to untreated plants.

The purpose of this work to reduce the bad effects of low temFature stress in the late peas plantations which prevailing under the middle Egypt region conditions during this period of the year of two pea varieties i.e. Entsar 1 and Master B with exogenous of foliar application with three stimulate substances i.e. Salicylic acid, Selenium and Green miracle at two concentrations from each of them as well as their interactions on the vegetative growth, days from beginning the flowering date, pollen grains viability \%, productivity and some chemical characters.

\section{MATERIALS AND METHODS}

These field experiments were carried out during the two winter seasons of 2015/2016 and 2016/2017 at Sids Horticulture Research Station, Beni Sueif Governorate, Agriculture Research Center, Egypt. The objectives of this investigation to study the reduction of the adverse effect of low temperature stress on growth and yield in the late plantations for two pea cultivars (Entsar 1 and Master B) by foliar spraying with three stimulate substances at two concentrations where adverse weather conditions prevailing for planting of this crop in that area during that time period of the year.

The meteorological data for the experimental area obtained from Central Laboratory for Agricultural Climate (CLAC), Agricultural Research Center (ARC), Ministry of Agricultural and Land Reclamation, values were recorded during the two growing seasons as shown in Table 1.

The experimental design was split-plot with three replicates. The main plots were devoted for two pea cultivars i.e. Enter 1 and Master B (factor A); foliar applications at two concentrations from each substance and control (tap water) were randomly distributed in sub plots (factor B). Foliar spraying with the stimulate substances treatments i.e. Salicylic $\operatorname{acid}^{\circledR}$ (Dihydroxybenzoic acid), manufactured by; El Nasr pharmaceutical chemicals Co. (Abu Zabale), used at a rate of 0.5 and $1 \mathrm{~g} / \mathrm{L}$, Selenium ${ }^{\circledR}$, Sodium Selenate $\left(\mathrm{Na}_{2} \mathrm{SeO}_{4}\right)$ F. W. 8.94, imported from Germany, used at a rate of 5 and $10 \mathrm{mg} / \mathrm{L}$, Green miracle ${ }^{\circledR}$ (Green miracle is an antitranspirant: Total amino acids not less than $3 \%$, Fatty alcohol $80 \%$, other neutral alcohol 10 $\%$, emulsifier and stabilizers $7 \%$ ), obtained from Gaara establishment for import and export (India), used at a rate of 3 and $6 \mathrm{~cm}^{3} / \mathrm{L}$ and control treatment (spraying with tap water). The $1^{\text {st }}$ foliar spraying with the different substances using in this investigation started after 25 days (after sowing date), the $2^{\text {nd }}$ spray achieved at beginning of the flowering for each cultivar and the $3^{\text {rd }}$ one was carried out after the $2^{\text {nd }}$ one with ten days during the plant growth period in the two winter seasons, respectively.

Table 1. Meteorological data at Sids, Beni Sueif Governorate region during the two winter seasons of 2015/2016 and 2016/2017

\begin{tabular}{lcccc}
\hline \multirow{1}{*}{ Months } & \multicolumn{4}{c}{ Temperature $^{\mathbf{0}} \mathbf{C}$} \\
& \multicolumn{2}{c}{$\mathbf{2 0 1 5 / 2 0 1 6}$} & \multicolumn{2}{c}{$\mathbf{2 0 1 6 / 2 0 1 7}$} \\
& Max. & Min. & Max. & Min. \\
\hline Dec. & 23.8 & 5.0 & 22.9 & 6.0 \\
Jun. & 23.9 & 8.0 & 22.5 & 8.2 \\
Feb. & 30.8 & 8.5 & 27.0 & 8.9 \\
March & 32.4 & 9.0 & 25.3 & 9.1 \\
\hline
\end{tabular}

The farm soil type was clay soil as Table 2 shows the physical and chemical properties of the experimental soil

Table 2. Physical and chemical properties of the experimental soil during the two winter seasons

\begin{tabular}{lcc}
\hline $\begin{array}{l}\text { Components } \\
\text { Soil Type }\end{array}$ & $\begin{array}{c}\mathbf{1}^{\text {st }} \text { season } \\
\text { Clay loam }\end{array}$ & $\begin{array}{c}\mathbf{2}^{\text {nd }} \text { season } \\
\text { Clay loam }\end{array}$ \\
\hline Organic Matter \% & 1.87 & 2.06 \\
Clay \% & 66.42 & 65.76 \\
Silt \% & 24.40 & 23.67 \\
Fine Sand \% & 8.55 & 9.86 \\
Coarse Sand \% & 0.63 & 0.71 \\
pH & 7.70 & 7.40 \\
E C (mmhos / cm) & 0.70 & 0.60 \\
CaCO3 \% & 2.70 & 2.90 \\
Available N (ppm) & 16.00 & 23.60 \\
Available P (ppm) & 7.60 & 5.90 \\
Available K (ppm) & 346.10 & 358.30 \\
\hline
\end{tabular}

Seeds for the two peas cultivars were purchased from the Horticulture Research Institute, Agricultural Research Center, Egypt and sown in the $1^{\text {st }}$ week in December of 2015/2016 and 2016/2017, in hills on one side of ridges at $10 \mathrm{~cm}$ apart. The plot area was $(10.8$ $\left.\mathrm{m}^{2}\right)$ and included 6 ridges each of $(0.6 \mathrm{~m})$ width and $(3.0$ m) length. All recommended agricultural practices of pea in this area such as irrigation, fertilization and pest management were applied during the two growing seasons according to the recommendations of Egyptian Ministry of Agriculture.

\section{Data recorded:}

\section{Vegetative growth characters:}

Five plants were taken randomly from the $2^{\text {nd }}$ and $4^{\text {th }}$ ridges for each plot after ten days from the last sprayer for each cultivar (at the flowering and pod setting stage) to measure the following vegetative growth characters i.e. plant height $(\mathrm{cm})$, number of branches/ plant and dry weight of foliage/ plant (g).

Beginning of the flowering date and pollen grains viability \% characters:

1- Beginning of the flowering date (days after sowing).

2- Pollen grains viability $\%$ was determined after 7 days from the last sprayer. Five randomly selected at whole flowers per each three plants at appropriate stage 
(full bloom) for studying pollen fertility, according to the method described by Ruzin (1999).

\section{Yield and its components:}

At suitable mature green pods stage, pods were continuously harvested for the two ridges $\left(3^{\text {rd }}\right.$ and $\left.5^{\text {th }}\right)$ to calculate the total green pods yield (ton/ fed). A random sample of 20 fresh green pods from five plants in the $2^{\text {nd }}$ picking were taken to determine average, each of number of pods/ plants, pod length $(\mathrm{cm})$, pod diameter $(\mathrm{cm})$, green pod weight $(\mathrm{g})$, number of seeds/ pod, seeds weight/ pod (g) and shell out percentage.

\section{Shell out percentage $=\underline{\text { Weight of green seeds }} \times \%$}

Weight of green pods

Chemical constituents of pea leaves and seeds:

\section{1- Minerals contents:}

The wet digestion in fresh leaves and seeds was determined according to the method described by Thomas (1967), to determine: total nitrogen, phosphorus and potassium contents (\%) were according to Pregl (1945), King (1951) and Brown and Jackson (1955), respectively. Protein contents (\%) in dry seeds were determined through the determination of seeds total nitrogen and a factor of 6.25 was used for conversion of total nitrogen to protein percentage according to Kelly and Bliss (1975).

2-Photosynthetic pigments: total chlorophyll content (mg/ $100 \mathrm{~g}$ fresh weight) was determined in the fresh leaves after ten days from the last sprayer for each cultivar, according to the method described by Nagata and Yamashita (1992).

3-Total sugars content (\%) in dry leaves and seeds were determined according to (Dubois et al., 1975).

4-The free proline content (\%) in dry leaves was determined according to Troll and Lindsley (1955).

\section{Statistical analysis:}

All obtained data of the present study was subjected to the analysis of variance techniques according to the design used by the MSTATC computer software program variance and the mean of treatments were compared according to the Least Significant Differences (L S D) test at the 0.05 probability level, method described by (Bricker, 1991).

\section{RESULTS AND DISCUSSION}

\section{I- Vegetative growth characters:}

The tabulated mean values in Table 3 on the vegetative growth characters revealed that, Entsar $1 \mathrm{cv}$. gave the highest significant values of plant height and dry weight/ plant except number of branches/ plant compared to Master B cv., in the two seasons. Foliar spraying with Green miracle at the lowest concentration i.e. $3 \mathrm{~cm}^{3} / \mathrm{L}$ obtained the highest number of branches for the two pea varieties, the best stimulate substance of the tested materials have led to significant increases in plant height and dry weight/ plant were Green miracle followed by selenium and salicylic acid at the highest concentrations as compared with tap water (control), during the two winter seasons.

Concerning, the interactions between the two factors, there were significant interaction between all the treatments especially, treated Entsar 1 variety with the Green miracle at a rate of $6 \mathrm{~cm}^{3} / \mathrm{L}$ in plant height and dry weight/ plant and $3 \mathrm{~cm}^{3} / \mathrm{L}$ in number of branches followed with Selenium and Salicylic acid at the highest rate in vegetative growth characters compared with the other variety and the control treatment. In this concern, Sharma et al. (2005) observed that cold stress induced morphological symptoms like; stunted, bushy plants, early maturity, yellowing of leaves. Modifications of cellular components include swelling of mitochondria, plastids and thylakoid lamellae, vesiculation of thylakoid and the disorganization of the entire plastid, during chilling stress as well as chilling results in accelerated senescence and eventually plant death.

These results of spraying Salicylic acid coincided with those reported by Eman et al. (2016) generalized that spraying snap bean plants under the low temperature conditions with Salicylic acid at a rate of 1 $\mathrm{mM} / \mathrm{L}$ obtained the highest values of plant length, fresh and dry weights.

The positive results of Selenium as foliar application may be due to increase resistance and antioxidant enzyme activity, decrease membrane damage and capacity of plants subjected to various stresses included low temperature stress, it can scavenge reactive oxygen species content. The present results were agreed with that reported by Boghdady et al. (2017) assumed that foliar application with $10 \mathrm{ppm}$ selenium/ L significant improvement effects on plant height, number of branches and leaves, fresh and dry weights of shoot/ plant of faba bean plants.

Regarding to the beneficial effects of Green miracle substance which contains total amino acids not less than $3 \%$, Geeth and Galal (2014) indicate that Palmoral pea cv. significantly enhanced the vigor growth than Jaguar pea cv. There was a significant increase with spraying amino acids (12\% free amino acids) at rate of $100 \mathrm{ppm} / \mathrm{L}$ as well as the interaction between varieties and spraying amino acids in the number of branches.

Beginning of the flowering date and pollen grains viability $(\%)$ characters:

The results in Table 4 exhibited that there were significant differences in the beginning of flowering date (days after sowing) and pollen grains viability (\%) between the two pea cultivars, Master B cv. was earlier to appearance the $1^{\text {st }}$ flower. Entsar $1 \mathrm{cv}$. significantly delayed until the beginning of the flowering after sowing date. Entsar $1 \mathrm{cv}$. significantly increased pollen grains viability $(\%)$ in the $2^{\text {nd }}$ season only as compared with Master B.

The spray treatments showed significant differences at beginning of the flowering and the vitality of the pollen. The spraying with the lowest concentration of Green miracle led to an early start of the flowering and increased the vitality of the pollen, followed by spraying with the highest concentration of Selenium and Salicylic acid treatments as compared with tap water (control), during the two winter seasons. 
Table 3. Effect of foliar application of two pea cultivars with some stimulate substances on vegetative growth characters during the two winter seasons of 2015/2016 and 2016/2017

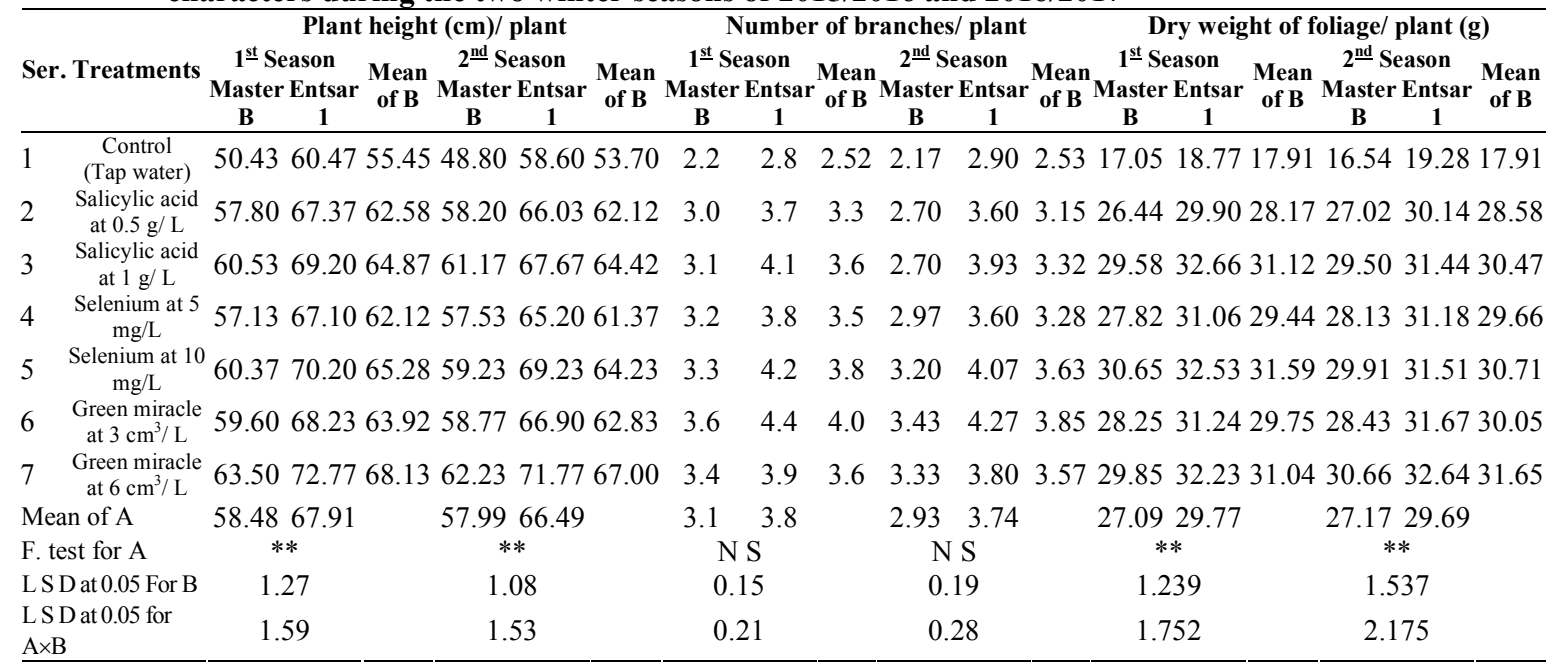

Table 4. Effect of foliar application of two pea cultivars with some stimulate substances at the beginning of flowering date (days after sowing) and the pollen grains viability during the two winter seasons of $2015 / 2016$ and $2016 / 2017$

\begin{tabular}{|c|c|c|c|c|c|c|c|c|c|c|c|c|c|}
\hline \multirow{3}{*}{ Ser. } & \multirow{3}{*}{ Treatments } & \multicolumn{6}{|c|}{ Beginning of the flowering date (days after sowing) } & \multicolumn{6}{|c|}{ Pollen grains viability $(\%)$} \\
\hline & & \multicolumn{2}{|c|}{$1^{\text {st }}$ Season } & \multirow{2}{*}{$\begin{array}{c}\text { Mean } \\
\text { of B }\end{array}$} & \multicolumn{2}{|c|}{$2^{\text {nd }}$ Season } & \multirow{2}{*}{$\begin{array}{c}\text { Mean } \\
\text { of B }\end{array}$} & \multicolumn{2}{|c|}{$1^{\text {st }}$ Season } & \multirow{2}{*}{$\begin{array}{c}\text { Mean } \\
\text { of B }\end{array}$} & \multicolumn{2}{|c|}{$2^{\text {nd }}$ Season } & \multirow{2}{*}{$\begin{array}{c}\text { Mean } \\
\text { of B }\end{array}$} \\
\hline & & Master I & ntsar 1 & & Master B & Entsar 1 & & Master E & Entsar 1 & & Master $\mathbf{E}$ & Entsar 1 & \\
\hline 1 & Control(Tap water) & 35.87 & 44.50 & 40.18 & 35.87 & 44.57 & 40.22 & 70.60 & 69.60 & 70.10 & 70.43 & 70.30 & 70.37 \\
\hline 2 & Salicylic acid at $0.5 \mathrm{~g} / \mathrm{L}$ & 34.67 & 42.57 & 38.62 & 34.63 & 42.93 & 38.78 & 74.93 & 77.53 & 76.23 & 75.23 & 76.83 & 76.03 \\
\hline 3 & Salicylic acid at $1 \mathrm{~g} / \mathrm{L}$ & 33.30 & 40.33 & 36.82 & 33.33 & 41.07 & 37.20 & 78.70 & 79.50 & 79.10 & 79.07 & 79.97 & 79.52 \\
\hline 4 & Selenium at $5 \mathrm{mg} / \mathrm{L}$ & 34.57 & 42.60 & 38.58 & 34.67 & 42.73 & 38.70 & 74.30 & 78.23 & 76.27 & 74.10 & 78.40 & 76.25 \\
\hline 5 & Selenium at $10 \mathrm{mg} / \mathrm{L}$ & 33.37 & 40.40 & 36.88 & 33.57 & 41.10 & 37.33 & 79.30 & 80.07 & 79.68 & 79.17 & 80.53 & 79.85 \\
\hline 6 & Green miracle at $3 \mathrm{~cm}^{3} / \mathrm{L}$ & 32.13 & 40.10 & 36.12 & 32.77 & 40.40 & 36.58 & 80.90 & 81.93 & 81.42 & 80.90 & 81.63 & 81.27 \\
\hline 7 & Green miracle at $6 \mathrm{~cm}^{3} / \mathrm{L}$ & 33.43 & 41.53 & 37.48 & 33.80 & 41.23 & 37.52 & 79.00 & 80.40 & 79.70 & 78.60 & 80.27 & 79.43 \\
\hline \multicolumn{2}{|c|}{ Mean of A } & 33.91 & 41.72 & & 34.09 & 42.01 & & 76.82 & 78.18 & & 76.79 & 78.28 & \\
\hline \multicolumn{2}{|c|}{ F. test for A } & \multicolumn{2}{|c|}{$* *$} & \multicolumn{3}{|c|}{$* *$} & & \multicolumn{2}{|c|}{ N S } & \multicolumn{4}{|c|}{$* *$} \\
\hline \multicolumn{2}{|c|}{ L S D at 0.05 for B } & \multicolumn{2}{|c|}{0.36} & \multicolumn{3}{|c|}{0.47} & & \multicolumn{2}{|c|}{0.71} & \multicolumn{4}{|c|}{0.69} \\
\hline \multicolumn{2}{|c|}{ L S D at 0.05 for $A \times B$} & \multicolumn{2}{|c|}{0.50} & \multicolumn{3}{|c|}{0.66} & & \multicolumn{2}{|c|}{1.01} & \multicolumn{3}{|c|}{0.97} & \\
\hline
\end{tabular}

Data in the same Table 4 evidence that the interaction between the two pea cultivars and foliar spraying with the substances had significant effects on beginning of the flowering date (days after sowing) and pollen grains viability percentage, the best results were obtained from the interaction with the Green miracle spray at a concentration of $3 \mathrm{~cm}^{3} / \mathrm{L}$ on both cultivars followed by spraying with Selenium at a dose of $10 \mathrm{mg} / \mathrm{L}$, Salicylic acid at a dose of $1 \mathrm{~g} / \mathrm{L}$ and that the superiority of Master B $\mathrm{cv}$. at beginning of the flowering under the same spray treatments due to the natural of the growth of this cultivar. Similar results obtained with Kaur et al. (2008) who declared that cold stress decreased the rate and duration of seed filling and increased seed, pod abortion and producing smaller sized seeds in chickpea plants. Reproductive phases of the life cycle of plants are more vulnerable to cold stress; influenced diversely during the development of male gametophyte, low temperature causes disruption of meiosis, stunted development of the pollen grain, anther protein degradation, pollen sterility and pollen tube deformation. The simulative effect of spraying the stimulate substances on flowering and pollen grains viability could be attributed to its bio regulator effects on physiological and biochemical processes in pea plants such as ion uptake, cell elongation, cell division, enzymatic activities, induces the flowering, increases flower life, retard senescence and increases cell metabolic rate as well as increase the antioxidant capacity, similar results were reported by many workers concerning the effect of Amino acid, Selenium and Salicylic acid on flowering like, Gad El-Hak et al. (2012) on pea plants, Malik et al. (2012) on mungbean plants and Geeth and Galal (2014) on pea plants.

Yield and its components:

Data pertaining in Tables 5, 6 and 7 illustrated that Entsar $1 \mathrm{cv}$. superior significant increases in the total yield (ton/fed) and its components, which gave the highest total pods yield as well as its components compared with Master B cv. On the other hand, Master B cv. significantly increased shell out $\%$ compared with the $2^{\text {nd }}$ cultivar. In this connection, non-significantly increased were occurred between the two cultivars on number of green seeds/ pod in the $2^{\text {nd }}$ season, pod diameter and seeds weight/ pod in the two winter seasons. The distinguished substance foliar spray used was Green miracle at the lowest concentration which gave the most pronouns results on the previous results followed with Selenium then Salicylic acid substances at the highest concentrations as compared with spray by tap water (control) treatment. Data in the same Tables 5, 6 and 7 indicated that there was a statistically significant effect of the interaction between the two pea cultivars and foliar spraying with the substances on the 
total pods yield and its components. The highest values of those data were recorded with the interaction of foliar application Entsar 1 cultivar by spraying Green miracle at a dose of $3 \mathrm{~cm}^{3} / \mathrm{L}$ followed with Selenium then Salicylic acid as substances at the highest concentrations when compared with the control (sprinkle by tap water) plants, these data held true in the both winter seasons. In this connection, the pod weight, number of pods/ plants, numbers of seeds/ pod and seeds weight/ pod were important yield components and contribute to the final total yield. Decreasing these terms in Master B cv. may be due to the genetic characteristics or environmental unsuitability (see Table, 2), which may hinder the process of pollination, fertilization or cause abortion as compared with Entsar 1 cv., Analogous findings were also attained by Ghulam et al. (2007) on pea cultivars and Eman et al. (2016) decided that spraying snap bean plants with Salicylic acid at a rate of $1 \mathrm{mM} / \mathrm{L}$ under the low temperature conditions, obtained the highest values of pod weight, marketable and the total pods yield (ton/fed).

Table 5. Effect of foliar application of two pea cultivars with some stimulate substances on number of pods/ plant, pod length and pod diameter during the two winter seasons of 2015/2016 and 2016/2017

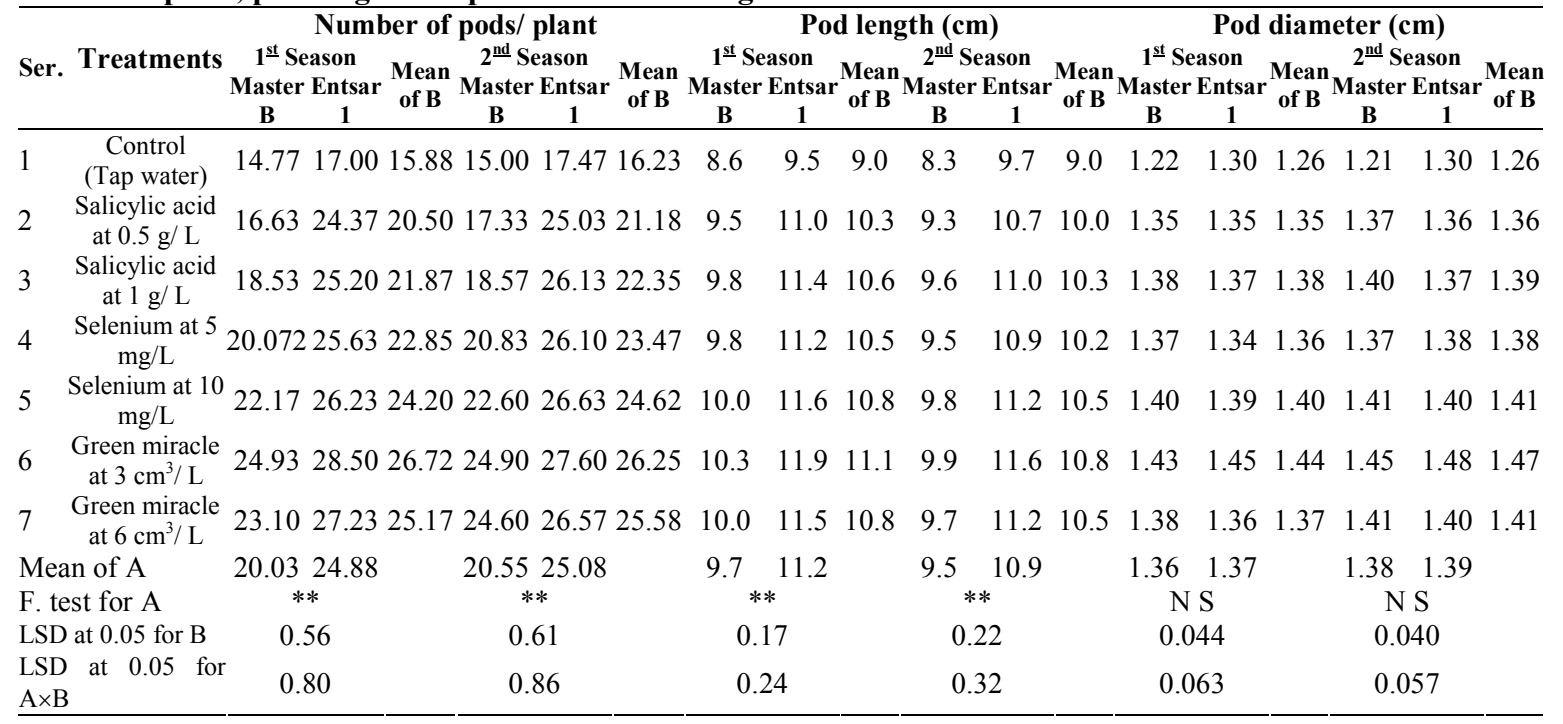

Table 6. Effect of foliar application of two pea cultivars with some stimulate substances on pod weight, number of seeds/ pod and seeds weight/ pod during the two winter seasons of 2015/2016 and 2016/2017

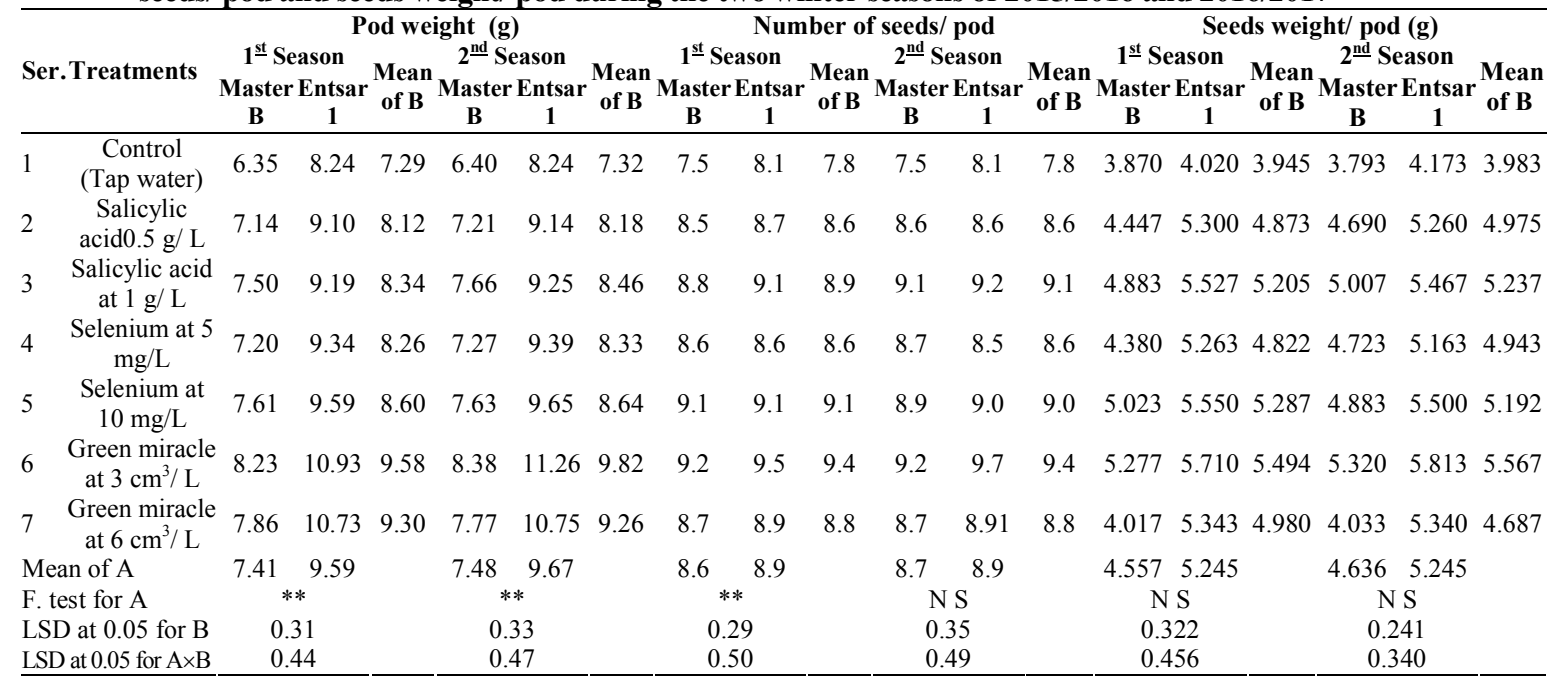

Results support the findings of enhancing effect of foliar application of Selenium element by Boghdady et al. (2017) who concluded that foliar application with $10 \mathrm{ppm}$ selenium/ L significant augmented the number of pods and seeds/plant, weight of 100 seeds and yield of seeds/ plant of faba bean plants.

Regarding, the Green miracle substance which contains total amino acids not less than $3 \%$, the favorable effects of Green miracle may be due to the amino acids which plays an important role in plant resistance to biotic and abiotic stresses. On the other hand, the amino acid increased the content and activity of endogenous plant growth regulators, which promote linear growth of plant organs due to its conversion into IAA. Auxins promote growth, increase building metabolites, retard senescence, enhance cell division, chlorophyll accumulation and stimulate dry matter production as a result of higher photosynthetic activity, consequently increased translocation and accumulation of micro elements in plant organs as well as building 
blocks of proteins. Similar results coincided with those reported by Raeisi et al. (2013) on faba bean plants as well as Geeth and Galal (2014) who elucidate that Palmoral cv. significantly enhanced the yield and its components of pea plants than Jaguar cv. Spraying amino acids at a rate of $100 \mathrm{ppm} / \mathrm{L}$ as well as the interaction between varieties and spraying amino acids significant increases in pod length, pod weight, number of seeds/ pod, fresh weight of seeds/ pod and the total pod yield (ton/ fed) and fresh weight of seeds/ pod.

Table 7. Effect of foliar application of two pea cultivars with some stimulate substances on shell out (\%) and total green pods yield during the two winter seasons of 2015/2016 and 2016/2017

\begin{tabular}{|c|c|c|c|c|c|c|c|c|c|c|c|c|c|}
\hline \multirow[b]{2}{*}{ Ser. } & \multirow[b]{2}{*}{ Treatments } & \multicolumn{6}{|c|}{ Shell out (\%) } & \multicolumn{6}{|c|}{ Total green pods yield (ton/ fed) } \\
\hline & & \multicolumn{2}{|c|}{$\begin{array}{c}1^{\text {st }} \text { Season } \\
\text { Master B Entsar } 1\end{array}$} & \multirow{2}{*}{$\begin{array}{c}\begin{array}{c}\text { Mean } \\
\text { of B }\end{array} \\
54.89\end{array}$} & $\begin{array}{r}2^{\text {nd }} \\
\text { Master }\end{array}$ & $\begin{array}{l}\text { Season } \\
\text { B Entsar 1 }\end{array}$ & \multirow{2}{*}{$\begin{array}{c}\begin{array}{c}\text { Mean } \\
\text { of B }\end{array} \\
54.96\end{array}$} & \multicolumn{2}{|c|}{$\begin{array}{c}1^{\text {st }} \text { Season } \\
\text { Master B Entsar 1 }\end{array}$} & \multirow{2}{*}{$\begin{array}{c}\begin{array}{c}\text { Mean } \\
\text { of B }\end{array} \\
3.355\end{array}$} & \multicolumn{2}{|c|}{$\begin{array}{c}2^{2^{\text {nd }}} \text { Season } \\
\text { Master B Entsar 1 }\end{array}$} & \multirow{2}{*}{$\begin{array}{c}\begin{array}{c}\text { Mean } \\
\text { of B }\end{array} \\
3.337\end{array}$} \\
\hline 1 & Control (Tap water) & 60.98 & 48.80 & & 59.30 & 50.61 & & 3.197 & 3.514 & & 3.160 & 3.513 & \\
\hline 2 & Salicylic acid at $0.5 \mathrm{~g} / \mathrm{L}$ & 62.36 & 58.21 & 60.29 & 65.07 & 57.54 & 61.31 & 3.638 & 4.025 & 3.832 & 3.660 & 4.083 & 3.872 \\
\hline 3 & Salicylic acid at $1 \mathrm{~g} / \mathrm{L}$ & 65.20 & 60.15 & 62.68 & 65.35 & 59.13 & 62.24 & 3.873 & 4.203 & 4.038 & 3.943 & 4.258 & 4.101 \\
\hline 4 & Selenium at $5 \mathrm{mg} / \mathrm{L}$ & 65.57 & 56.36 & 60.96 & 64.96 & 55.01 & 59.99 & 3.657 & 4.110 & 3.884 & 3.697 & 4.142 & 3.920 \\
\hline 5 & Selenium at $10 \mathrm{mg} / \mathrm{L}$ & 66.05 & 57.89 & 61.97 & 63.97 & 56.98 & 60.48 & 3.933 & 4.354 & 4.144 & 3.905 & 4.341 & 4.123 \\
\hline 6 & Green miracle at $3 \mathrm{~cm}^{3} / \mathrm{L}$ & 68.20 & 52.38 & 60.29 & 66.45 & 51.62 & 59.04 & 4.303 & 4.753 & 4.528 & 4.135 & 4.640 & 4.388 \\
\hline 7 & Green miracle at $6 \mathrm{~cm}^{3} / \mathrm{L}$ & 67.16 & 49.96 & 58.56 & 68.52 & 49.70 & 59.11 & 4.002 & 4.329 & 4.165 & 4.050 & 4.338 & 4.194 \\
\hline \multicolumn{2}{|c|}{ Mean of A } & 65.07 & 54.82 & & 64.80 & 54.37 & & 3.800 & 4.184 & & 3.793 & 4.188 & \\
\hline \multicolumn{2}{|c|}{ F. test for A } & \multicolumn{2}{|c|}{$* *$} & \multicolumn{3}{|c|}{$* *$} & \multicolumn{3}{|c|}{$* *$} & \multicolumn{4}{|c|}{$* *$} \\
\hline \multicolumn{2}{|c|}{ L S D at 0.05 for B } & \multicolumn{2}{|c|}{3.41} & \multicolumn{3}{|c|}{3.85} & \multicolumn{3}{|c|}{0.148} & \multicolumn{4}{|c|}{0.126} \\
\hline \multicolumn{2}{|c|}{$\mathrm{L} \mathrm{S} \mathrm{D} \mathrm{at} 0.05$ for $\mathrm{A} \times \mathrm{B}$} & \multicolumn{2}{|c|}{4.82} & \multicolumn{3}{|c|}{5.44} & \multicolumn{3}{|c|}{0.209} & \multicolumn{4}{|c|}{0.179} \\
\hline
\end{tabular}

\section{Chemical composition of pea leaves and seeds:}

Cultivation effect of Entsar 1 and Master B cultivars on chemical composition i.e. total chlorophyll (mg/ $100 \mathrm{~g}$ fresh weight), total sugars, proline, nitrogen, phosphorus and potassium contents $(\%)$ in pea leaves and total sugars as well as protein contents (\%) in pea seeds presented in Tables 8, 9 and 10 showed that, there were significant different between the two varieties from each other, Entsar 1 occurred obvious increasing in all chemical composition compared with Master B. Nonsignificant increasing was obtained in protein and potassium contents $(\%)$ in the $1^{\text {st }}$ season only as well as proline and phosphorus in the two seasons between the two cultivars, respectively. Foliar spraying with Green miracle as a stimulant substance at rate of $3 \mathrm{~cm}^{3} / \mathrm{L}$ able to significantly increase all chemical composition of pea cultivars followed with the two other substances with the highest concentrations as compared to tap water (control) treatment. Concerning to the interactions between the two pea varieties and the different concentrations of the stimulant substances show in the same Tables 8, 9 and 10, illustrated that treated Entsar $1 \mathrm{cv}$. with Green miracle substance as foliar spraying at a rate of $3 \mathrm{~cm}^{3} / \mathrm{L}$, was the most superior interaction treatment which condensed the all chemical composition of pea leaves and seeds followed by the rest two substances at the highest concentration as compared with Master B cv. in the same interaction.

Under the low temperature stress, the primary target of damages related to the photosynthesis, causing the generation of reactive oxygen species in the thylakoid membrane. These free radicals are able to damage to protein and pigments photosynthetic, (Horváth et al., 2007). The results of Salicylic acid reinforced with Vazirimehra and Khashayar (2014) who decided that Salicylic acid as an antioxidant substance concentrated in the chloroplast and protect the photosynthetic apparatus when a plant is subjected to stress, by scavenging the excessive reactive oxygen species known as free radicals. Salicylic acid plays a vital role in plant growth, ion uptake and transport. This positive effect of Salicylic acid could be attributed to an increased $\mathrm{CO}_{2}$ assimilation and photosynthetic rate and increased mineral uptake by the stressed plant. In this respect, Eman et al. (2016) commented that spraying snap bean plants under the low temperature conditions with Salicylic acid at a rate of 1 $\mathrm{mM} / \mathrm{L}$ obtained the highest values of nitrogen, phosphorus, potassium, total chlorophyll and carotenoids. As for, a stimulatory effect of foliar application of Selenium treatments, the increase in the total chlorophyll contents of pea leaves may be attributed to the role of Selenium effect over protection of chloroplast enzymes and thus increasing the biosynthesis of photosynthetic pigments as well as increased starch accumulation in chloroplasts. When plants are subjected to environmental stress, their chloroplasts are damaged, leading to disrupted photosynthesis. However, the addition of appropriate levels of Selenium can somewhat reduce the damage to the chloroplasts and increase the chlorophyll contents. Selenium application may be closely related to the decreased reactive oxygen species levels, reactivation of antioxidants, restored structure of the damaged chloroplasts and enhanced production of other vital metabolites. The previous findings coincided with those obtained by Renwei et al. (2013) and Boghdady et al. (2017) mentioned that foliar application with $10 \mathrm{ppm}$ selenium/ L significant enhancement in total chlorophyll, carotenoids (in leaves), percentages of nitrogen, phosphorus, potassium and crude protein (in seeds) content in faba bean plant.

Respecting, the favorable effects of stimulating Green miracle substance, in this orientation, Janska et al. (2009) who concluded that plant species acclimate during cold stress, by synthesis of cryoprotective molecules such as soluble sugars (saccharose, raffinose, stachyose and trehalose), sugar alcohols (sorbitol, ribitol and inositol) and low-molecular weight nitrogenous compounds (proline and glycine betaine). These results are came to the same conclusion with Geeth and Galal (2014) claimed that there were significantly increased between the two cultivars i.e. Palmoral and Jaguar the in protein $(\%)$ content in dry pea seeds. Spraying amino 
acids at a rate of $100 \mathrm{ppm} / \mathrm{L}$. and the interaction between varieties and spraying amino acids were significantly increased in nitrogen and protein $(\%)$ contents in dry pea seeds.

Table 8. Effect of foliar application of two pea cultivars with some stimulate substances on total chlorophyll, total sugars and proline contents in leaves during the two winter seasons of 2015/2016 and 2016/2017

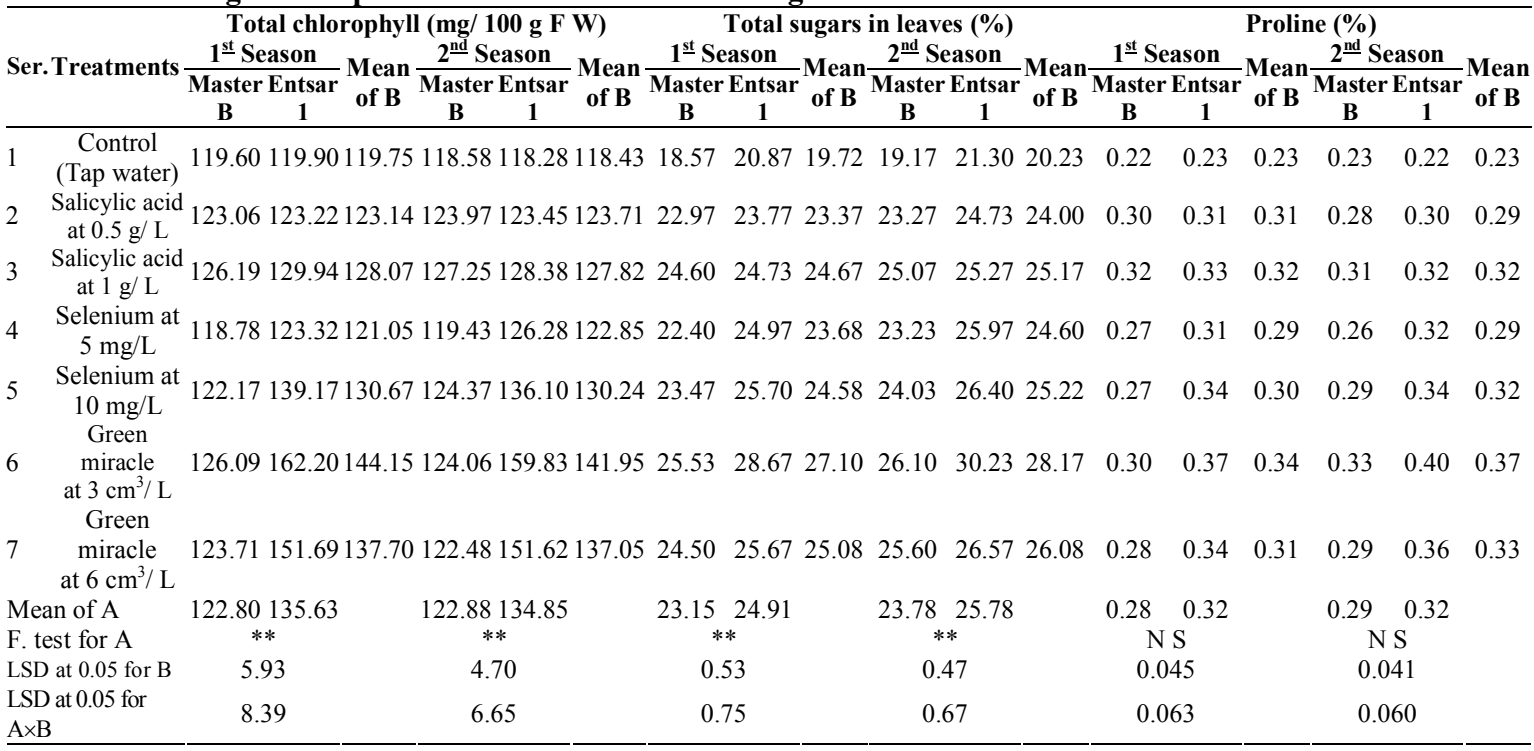

Table 9. Effect of foliar application of pea cultivars with some stimulate substances on total sugars and protein contents in seeds during the two winter seasons of 2015/2016 and 2016/2017

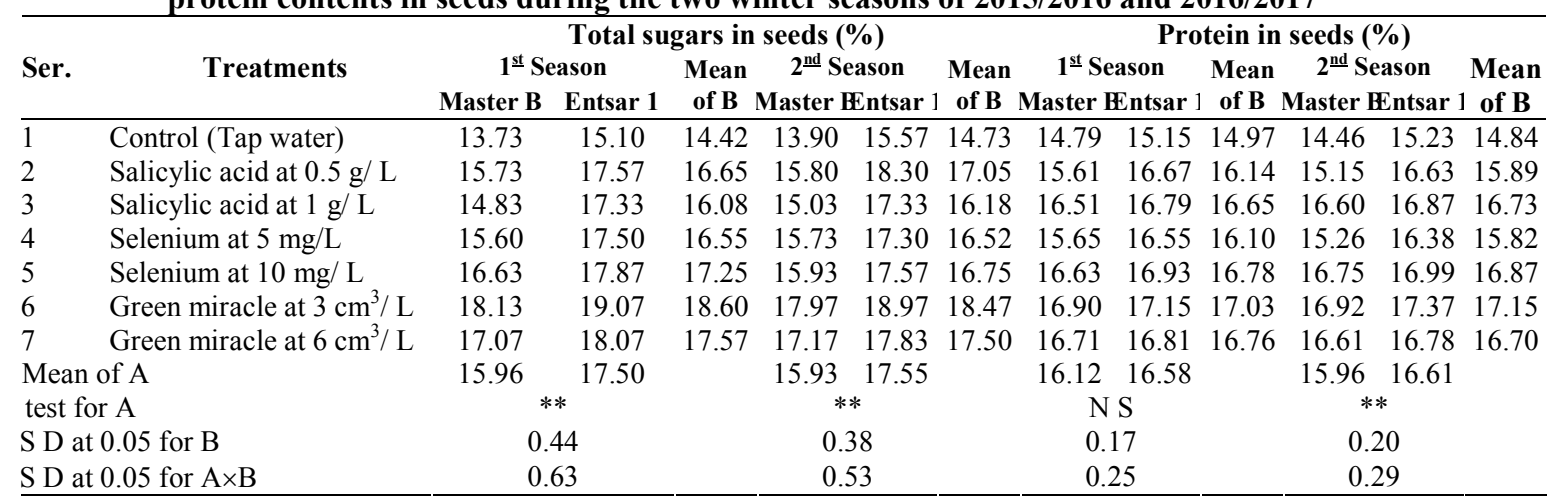

Table 10. Effect of foliar application of two pea cultivars with some stimulate substances on percentage of nitrogen, phosphorus and potassium contents in leaves during the two winter seasons of 2015/2016 and 2016/2017

\begin{tabular}{|c|c|c|c|c|c|c|c|c|c|c|c|c|c|c|c|c|c|c|c|}
\hline \multirow{3}{*}{ Ser. } & \multirow{3}{*}{ Treatments } & \multicolumn{6}{|c|}{ Nitrogen (\%) } & \multicolumn{6}{|c|}{ Phosphorus (\%) } & \multicolumn{6}{|c|}{ Potassium (\%) } \\
\hline & & \multirow{2}{*}{\multicolumn{2}{|c|}{\begin{tabular}{cc}
\multicolumn{2}{c}{$1^{\text {st }}$ Season } \\
Master & Entsar \\
B & 1 \\
\end{tabular}}} & \multirow{2}{*}{$\begin{array}{c}\text { Mean } \\
\text { of B }\end{array}$} & \multirow{2}{*}{\multicolumn{2}{|c|}{$\begin{array}{c}2^{\text {nd }} \text { Season } \\
\text { Master Entsar } \\
\text { B } \quad 1 \\
\end{array}$}} & \multirow{2}{*}{$\begin{array}{c}\text { Mean } \\
\text { of } B\end{array}$} & \multirow{2}{*}{\multicolumn{2}{|c|}{$\begin{array}{cc}1^{\text {st }} \text { Season } \\
\text { Master Entsar } \\
\text { B } \quad 1 \\
\end{array}$}} & \multirow{2}{*}{$\begin{array}{c}\text { Mean } \\
\text { of } B\end{array}$} & \multicolumn{2}{|c|}{$\begin{array}{l}2^{\text {nd }} \text { Season } \\
\text { Master Entsar }\end{array}$} & \multirow{2}{*}{$\begin{array}{c}\text { Mean } \\
\text { of B }\end{array}$} & \multicolumn{2}{|c|}{$\begin{array}{c}1^{\text {st }} \text { Season } \\
\text { Master Entsar }\end{array}$} & \multirow{2}{*}{$\begin{array}{c}\text { Mean } \\
\text { of } \mathbf{B}\end{array}$} & \multicolumn{2}{|c|}{$\begin{array}{c}2^{\text {nd }} \text { Season } \\
\text { Master Entsar }\end{array}$} & \multirow{2}{*}{$\begin{array}{c}\text { Mean } \\
\text { of B }\end{array}$} \\
\hline & & & & & & & & & & & B & 1 & & B & 1 & & B & 1 & \\
\hline 1 & $\begin{array}{c}\text { Control } \\
\text { (Tap water) }\end{array}$ & 2.18 & 2.21 & 2.20 & 2.18 & 2.21 & 2.19 & 0.340 & 0.363 & 0.352 & 0.343 & 0.357 & 0.350 & 2.323 & 2.330 & 2.327 & 2.353 & 2.357 & 2.355 \\
\hline 2 & $\begin{array}{c}\text { Salicylic acid } \\
\text { at } 0.5 \mathrm{~g} / \mathrm{L}\end{array}$ & 2.20 & 2.57 & 2.38 & 2.19 & 2.59 & 2.39 & 0.350 & 0.420 & 0.385 & 0.363 & 0.440 & 0.402 & 2.407 & 2.483 & 2.445 & 2.383 & 2.517 & 2.450 \\
\hline 3 & $\begin{array}{c}\text { Salicylic acid } \\
\text { at } 1 \mathrm{~g} / \mathrm{L}\end{array}$ & 2.21 & 2.70 & 2.46 & 2.21 & 2.72 & 2.47 & 0.367 & 0.440 & 0.403 & 0.383 & 0.463 & 0.423 & 2.490 & 2.523 & 2.507 & 2.487 & 2.573 & 2.530 \\
\hline 4 & $\begin{array}{c}\text { Selenium at } 5 \\
\mathrm{mg} / \mathrm{L}\end{array}$ & 2.33 & 2.66 & 2.50 & 2.34 & 2.71 & 2.53 & 0.370 & 0.430 & 0.400 & 0.387 & 0.457 & 0.422 & 2.377 & 2.500 & 2.438 & 2.370 & 2.543 & 2.457 \\
\hline 5 & $\begin{array}{l}\text { Selenium at } 10 \\
\mathrm{mg} / \mathrm{L}\end{array}$ & 2.38 & 2.79 & 2.58 & 2.38 & 2.86 & 2.62 & 0.400 & 0.457 & 0.428 & 0.407 & 0.480 & 0.443 & 2.487 & 2.543 & 2.515 & 2.467 & 2.607 & 2.537 \\
\hline 6 & $\begin{array}{l}\text { Green miracle } \\
\text { at } 3 \mathrm{~cm}^{3} / \mathrm{L}\end{array}$ & 2.59 & 3.22 & 2.91 & 2.68 & 3.28 & 2.98 & 0.410 & 0.457 & 0.433 & 0.413 & 0.520 & 0.467 & 72.497 & 2.640 & 2.568 & 2.513 & 2.743 & 2.628 \\
\hline 7 & $\begin{array}{l}\text { Green miracle } \\
\text { at } 6 \mathrm{~cm}^{3} / \mathrm{L}\end{array}$ & 2.45 & 3.10 & 2.78 & 2.55 & 3.09 & 2.82 & 0.390 & 0.433 & 0.412 & 0.390 & 0.447 & 0.418 & 2.450 & 2.580 & 2.515 & 2.420 & 2.590 & 2.505 \\
\hline \multicolumn{2}{|c|}{ Mean of A } & 2.33 & 2.75 & & 2.36 & 2.78 & & 0.375 & 0.429 & & 0.384 & 0.452 & & 2.433 & 2.514 & \multirow{2}{*}{\multicolumn{3}{|c|}{$2.428 \quad 2.561$}} & \\
\hline \multicolumn{2}{|c|}{ F. test for A } & \multicolumn{2}{|c|}{$* *$} & \multicolumn{3}{|c|}{$* *$} & \multicolumn{3}{|c|}{ N S } & \multicolumn{3}{|c|}{ N S } & \multicolumn{3}{|c|}{ N S } & & & & \\
\hline \multicolumn{2}{|c|}{ L S D at 0.05 for $B$} & \multicolumn{2}{|c|}{0.06} & \multicolumn{3}{|c|}{0.05} & \multicolumn{3}{|c|}{0.05} & \multicolumn{3}{|c|}{0.04} & \multicolumn{3}{|c|}{0.034} & \multicolumn{3}{|c|}{0.037} & \\
\hline L S D & at 0.05 for $\mathrm{A} \times \mathrm{B}$ & 0.0 & & & 0.0 & 06 & & & 06 & & & 06 & & & 049 & & & 065 & \\
\hline
\end{tabular}




\section{The recommendations}

To reduce the bad effect of the weather conditions due to the low temperature stress in the Middle Egypt Region and the possibility of pea plantations during the month of December it is recommended to cultivate Entsar $1 \mathrm{cv}$. with foliar spraying with stimulate substance of Green miracle at a rate of $3 \mathrm{~cm}^{3} / \mathrm{L}$.

\section{REFERENCES}

Boghdady, M. S.; E. M. Desoky; S. N. Azoz and M. A. Dalia Nassar (2017). Effect of selenium on growth, physiological aspects and productivity of faba bean (Vicia faba L.). Egypt Agron, 39, (1): 83- 97.

Bricker, B. (1991). MSTATC: A micro computer program from the design management and analysis of agronomic research experiments. Michigan State Univ. USA.

Brown, J. G. and P. K. Jackson (1955). Anate on the potentiometric determination of chloride. Proc. Amer. Soc. Hort. Sci., 65:187-194.

Clarke, H. J, T. N. Khan and K. H. M. Siddique (2004). Pollen selection for chilling tolerance at hybridisation leads to improved chickpea cultivars. Euphytica, 139:65-74.

Dubois, M.; K. M. Gilles; J. K. Hamilton; P. A. Robers and F. Smith (1975). Calorimetric method for determination of sugars and related substances. Anolyt., Chem., 28(3): 350 -356.

Elzebroek, T. and K. Wind (2008). Guide to cultivated plants. CAB International, Oxfordshire, UK.

Eman, S. T.; M. E. Ragab; S. A. AbdEl-hady and A. H. Amer (2016). The possibility of green bean production in the off-season open field despite low temperature under Egyptian conditions. Middle East J. Agric., 05 (04): 534-543.

Gad El-Hak, S. H.; A. M. Ahmed and Y. M. M. Moustafa (2012). Effect of foliar application with two antioxidants and humic acid on growth, yield and yield components of peas (Pisum sativum L.). J. Horti. Sci. \& Ornamental Plants, 4 (3): 318-328.

Geeth, R. H. M. and R. M. Galal (2014). Response of pea plant (Pisum sativum L.) growth and yield for spraying of amino acids and boron. Egypt. J. of Appl. Sci., 29 (3):154-173.

Ghulam, M.; A. Rehana; A. Shahbaz and A. Syed (2007). The yield and yield components of pea (Pisum sativum L.) as influenced by salicylic acid. Pakistan. j. Bot., 39(2): 551-559.

Hawrylak-Nowak, B.; R. Matraszek and M. Szymanska (2010). Selenium modifies the effect of shortterm chilling stress on cucumber plants, Biol. Trace Elem., 10:8613-8615.

Heba, S. A.; S. M. Shehata; A. M. El-Gizawy; A. Abou El-Yazied and S. M. Adam (2015). Snap bean response to salicylic acid and putrescine used separately and jointly under two sowing dates. Middle East J. Applied Sci.,:05:(04): 1211-1221.
Horváth, E; G. Szalai and T. Janda (2007). Induction of abiotic stress tolerance by Salicylic acid signaling. Review, Plant Growth Regulation, 26:290-300.

Janska, A.; P. Mars; S. Zelenkova and J. Ovesna (2009). Cold stress and acclimation-what is important for metabolic adjustment? Plant Biol., 12:395-405.

Kaur, G.; S. Kumar; H. Nayyar and H. D. Upadhyaya (2008). Cold stress injury during the pod-filling phase in chickpea (Cicer arietinum L.): effects on quantitative and qualitative components of seeds. J. Agron. Crop Sci., 194:457-464.

Kelly, J. D. and F. A. Bliss (1975). Heritability estimates of percentage seeds protein and available methionine and correlations with yield in dry bean. Crop Sci., 15:753-757.

King, E. J. (1951). Micro-Analysis in Medical Biochemistry. $2^{\text {nd }}$ Ed., Churchil, Landon, (C F Comp. Search).

Kumar, K; S. Solanki; S. N. Singh and M. A. Khan (2016) Abiotic constraints of pulse production in India. Disease of pulse crops and their sustainable management,: 23-39. Biotech Books, New Delhi, India.

Malik, J. A.; S. Goel; N. Kaur; S. Sharma; I. Singh and H. Nayyar (2012). Selenium antag-onises the toxic effects of arsenic on mungbean (Phaseolus aureus Roxb.) plants by restricting its uptake and enhancing the antioxidative and detoxification mechanisms. Environmental and Experimental Botany, 77:242-248.

Mutlu, S.; Ö. Karadağoğlu; Ö. Atici and B. Nalbantoğlu (2013). Protective role of Salicylic acid applied before cold stress on antioxidative system and protein patterns in barley apoplast. Biologia Plantarum, 57 (3): 507-513.

Nagata, M. and I. Yamashita (1992). Simple method for simultaneous determination of chlorophyll and carotenoids in tomato fruit. J. Japan Soc. Food Sci., Technol., 39: 928-932.

Pregl, F. (1945). Quantitative Organic Micro Analysis. $4^{\text {th }}$, Ed. J. and Churchill Ltd. London, (C F Comp. Search).

Raeisi, M; L. Farahani and S. Shams (2013). Effects of chemical fertilizers and bio stimulants containing amino acid on yield and growth parameters of broad bean (Vicia faba L.). Intern. J. Agric., Crop Sci., 5(21):2618-2621.

Renwei, F.; W. Chaoyang and T. Shuxin (2013). The roles of Selenium in protecting plants against abiotic stresses. Environ., and Experimental Botany, 87:58- 68 .

Ruzin, S. E. (1999). Plant micro technique and microscopy. Oxford University Press, London.

Sharma, P.; N. Sharma and R. Deswal (2005). The molecular biology of the low temperature response in plants. BioEssays, 27:1048-1059.

Tapiero, H; D. M. Townsend and K. D. Tew (2003). The antioxidant role of selenium and selenocompounds. Biomed. Pharmacother. 57(34): 134-144. 
Thomas, A. J. R. (1967). The rule of the ring. J. Cell. Vazirimehra, M. R. and R. Khashayar (2014). Effect of Physiol., 70: (Suppl. 1) 13-34.

Troll, W. and J. Lindsley (1955). A photometric method for determination of proline. J. Biol., Chem., 215: Salicylic acid in agriculture. Int. J. Plant, Animal $655-660$ and Environ., Sci.,: 291- 296.

\section{تأثير الرش الورقى ببعض المواد على إجهاد الحرارة المنخفضة على النمو والإنتاجية فى زراعات البسلة المتأخرة

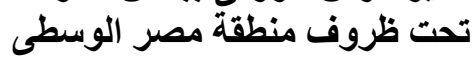

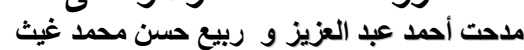

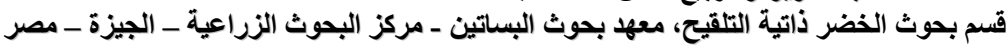

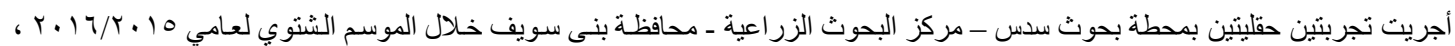

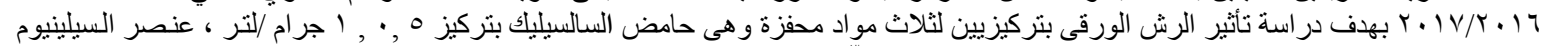

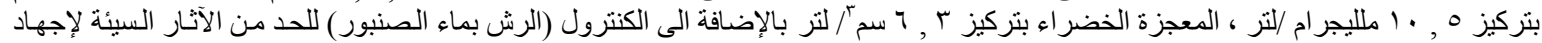

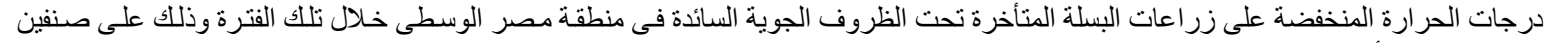

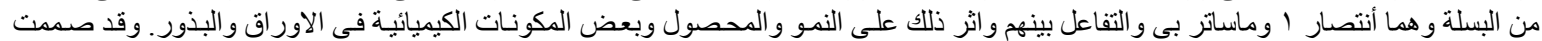

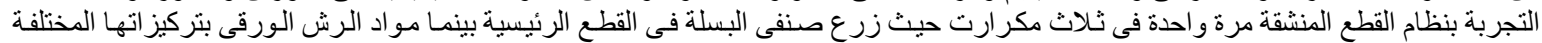

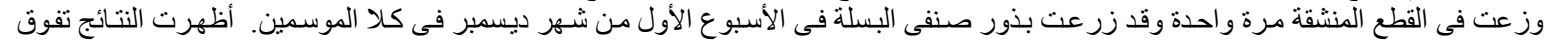

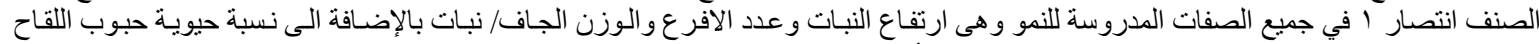

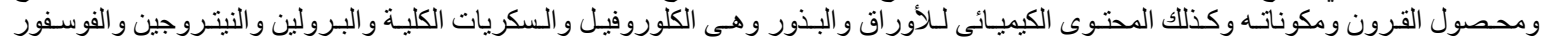

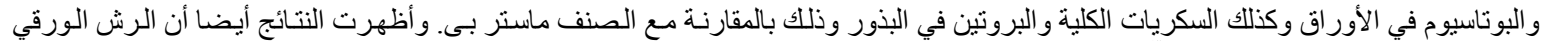

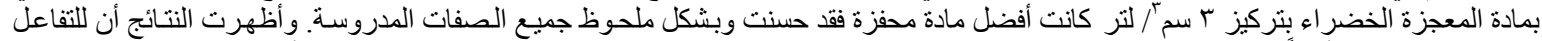

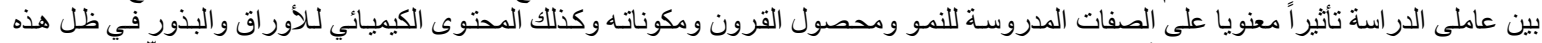

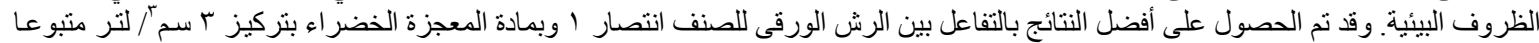

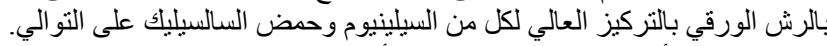

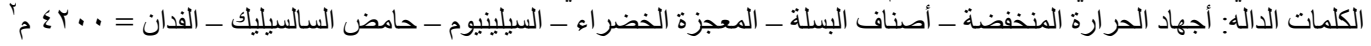

